\title{
Influence of the instrument used for cervical preflaring on the precision of 2 Eletronic Apex Locators
}

\author{
Influência do instrumento utilizado no preparo cervical na precisão de 2 localizadores apicais eletrônicos
}

\author{
Bruno Martini GUIMARÃES 1 \\ Talita TARTARI' \\ Samuel Lucas FERNANDES ${ }^{1}$ \\ Denise Ferracioli ODA ${ }^{1}$ \\ Clovis Monteiro BRAMANTE ${ }^{1}$ \\ Marco Antonio Hungaro DUARTE ${ }^{1}$
}

\section{ABSTRACT}

\section{Objective}

This study was aimed at evaluating the influence of cervical preflaring using LA-Axxes No. 1 bur (SybronEndo, Glendora, USA) or S1 and SX ProTaper files (Dentsply Maillefer, Ballaigues, Switzerland) on the accuracy of the Electronic Apex Locators (EALS): Root ZX mini (J. Morita Corporation, Tokyo, Japan), and Joypex 5 (Denjoy, Changsha, China).

\section{Methods}

Thirty mandibular incisors were accessed, and the root canal length (RCL) was determined with a K-file \#15, with the aid of a stereo microscope. Afterwards, the specimens were divided into 2 groups $(n=15)$ referring to the cervical preflaring with LA-Axxess or ProTaper files. The teeth were embedded in alginate and the $R C L$ was determined by the EALs before and after preflaring. Data were classified into: accurate, if the difference in $R C L$ measurement were $\leq 0.05 \mathrm{~mm}$; and inaccurate, if the difference were $>0.5 \mathrm{~mm}$ or beyond the $R C L$.

\section{Results}

McNemar's test $(\alpha<0.05)$ was used to detect differences in the accuracy of the EALs before and after each preflaring with different instruments, and to detect difference in accuracy among devices. No differences were found concerning the accuracy of the EALS $(P>0.05)$ after the cervical preflaring, regardless of the used instrument.

\section{Conclusion}

The preflaring procedure increased the number of accurate measurements for both EALs, with statistical difference for Joypex 5 when the preflaring was performed with LA-Axxess. However, after the cervical preflaring, the EALs showed similar accuracy, regardless of the used instrument.

Indexing terms: Dental instruments. Endodontics. Odontometry.

\section{RESUMO}

\section{Objetivo}

Avaliar a influência do preparo cervical utilizando a broca LA-Axxess n 1 (SybronEndo, Glendora, EUA) ou os instrumentos ProTaper S1 e SX (Dentsply Maillefer, Ballaigues, Suíça) na precisão dos Localizadores Apicais Eletrônicos (LAEs): Root ZX mini (J. Morita Corporation, Tóquio, Japão) e Joypex 5 (Denjoy, Changsha, China).

\section{Métodos}

Trinta incisivos inferiores foram acessados e o comprimento do canal radicular (CCR) determinado com uma lima K \#15 com o auxílio de um estereomicroscópio. Em seguida, os dentes foram distribuídos em dois grupos $(n=15)$ referentes ao preparo cervical com LA-Axxess ou instrumentos ProTaper. Os dentes foram incluídos em alginato e o CCR determinado pelos LAEs antes e após o preparo cervical. Os dados foram classificados em: precisos, se a diferença na medida do CCR era $\leq 0,05 \mathrm{~mm}$; e imprecisos, se a diferença era $>0,5 \mathrm{~mm}$ ou estava além do CCR.

\section{Resultados}

O teste de McNemar $(\alpha<0.05)$ foi utilizado para detectar diferenças na precisão dos LAEs antes e após o preparo com os diversos instrumentos, e para detectar diferenças na precisão entre os aparelhos. Não foram identificadas diferenças na precisão entre os dois LAEs $(P>0,05)$ após 0 preparo cervical, indiferente do instrumento utilizado.

\section{Conclusão}

O preparo cervical aumentou o número de medições precisas dos LAEs, com diferença estatística para Joypex 5 após o uso da LA-Axxess, contudo os aparelhos apresentaram precisão similar após o preparo cervical, indiferente do instrumento utilizado.

Termos de indexação: Instrumentos odontológicos. Endodontia. Odontometria.

\footnotetext{
${ }^{1}$ Universidade de São Paulo, Faculdade de Odontologia de Bauru. Al. Octávio Pinheiro Brisolla, 9-75, 17012-901, Bauru, SP, Brasil. Correspondência para / Correspondence to: BM GUIMARÃES. E-mail: <brunomgui@usp.br>.
} 


\section{INTRODUCTION}

The determination and maintenance of apical limit during root canal preparation has a fundamental importance to obtain a safe and efficient endodontic instrumentation ${ }^{1}$. The recommended reference point to determine the working length $(\mathrm{WL})$, ideal depth for instrumentation and endodontic obturation, is the apical portion of the root canal, which offers greater constriction and can be found at $0.5-1.0 \mathrm{~mm}$ short of the major apical foramen ${ }^{2}$. However, obtaining WL using conventional radiographic method is hindered by the limitations related to this technique, such as image distortion, and variations and interference of anatomical structures, which can reduce the reliability of the obtained measurement ${ }^{1-5}$.

Electronic Apex Locators (EALs) have been introduced in Endodontics with the goal of making the determination of the $\mathrm{WL}$, or apical constriction, of the root canal more accurate and reliable ${ }^{6}$. These devices have been constantly changed since they were invented. The changes, which were related to their operating principle, have been made in order to achieve more accurate measurements. Thencefore, EALs have gained popularity in endodontics ${ }^{7}$. The latest EALS use the principle of alternating current impedance with the processing of two or more different frequencies ${ }^{8-10}$. Currently, one of the EALs which has presented satisfactory results is the Mini Root ZX (J. Morita Corp., Tokyo, Japan) ${ }^{11}$, a modified version of Root ZX from the same manufacturer ${ }^{10}$, which measures the impedance of two frequencies simultaneously ${ }^{12}$. Due to its high cost, some professionals are purchasing EALs that are more financially viable, such as Joypex 5 (Denjoy, Changsha, China), which uses multiple frequencies, though there are few studies verifying their efficiency, especially when associated with cervical enlargement.

Cervical preparations are intended to facilitate the insertion of the instruments up to the apical third of the root canal ${ }^{13-15}$, and reduce the amount of microorganisms that can be pushed to the periapical zone ${ }^{16}$. This procedure can be performed using manual or mechanical techniques ${ }^{17}$, with the aid of different instruments, such as Hedstroem files, IT-Axxess and Gates-Glidden drills, and rotational instruments, such as the S1 and Sx by ProTaper system ${ }^{16,18,19}$. Studies have shown that when the determination of WL was performed without prior cervical enlargement, there was a higher incidence of cases where the file stopped short of or beyond the apical limit of the root canal ${ }^{14,16}$. To date, few studies that evaluated the influence of cervical preparation on measurements by EALS suggest that the accuracy of some devices was increased after cervical preparation ${ }^{15,20-21}$.

Although numerous studies indicate an increase in the accuracy concerning the determination of the WL by different EALs $5,7,22-24$, the fact that prior cervical preparation of root canals performed with different instruments might affect the accuracy of these devices has not yet been proved. Thus, this study was aimed at evaluating the influence of cervical preparation, using LA-Axxess (SybronEndo) and S1 and Sx ProTaper (Dentsply Maillefer), on the accuracy of Root ZX mini and Joypex 5.

\section{METHODS}

This study was approved by the Ethics Committee in Research (report \#165.371).

\section{Selection and preparation of the samples}

Thirty mandibular incisor teeth with a single root canal, extracted due to clinical indication and donated to this research with the prior consent of the patient, were selected for this study after radiographic examination. The selected teeth presented their root and coronary structures preserved, completely formed apex, root canal of type I of Vertucci ${ }^{25}$, and no evidence of calcification, resorption, fractures, endodontic treatment and metal restorations. Tissues and debris were removed from the root surface by manual curettes. The teeth were kept in saline solution at $5^{\circ} \mathrm{C}$ until the time they were going to be used.

The incisal edges were flattened using a polishing machine under refrigeration (APL-4; Arotec, Cotia, SP, Brazil) to obtain a fixed and stable reference point to assist future measurements of the root canal. Crown access was performed with diamond burs \# 1012 (S.S. White Dental products, Rio de Janeiro, RJ, Brazil) at high speed. Debris present in the pulp chamber and remnants of pulp tissue were removed with K file\#10 (Dentsply Maillefer, Ballaige, Switzerland) under irrigation with sodium hypochlorite solution $1 \%(\mathrm{NaOCL})$ using a disposable plastic syringe attached to a 23 gauge needle.

The length of the root canal (LRC) up to the apical foramen was determined by the introduction of a K file \#10 (Dentsply Maillefer, Ballaige, Switzerland) inside the canal up to the point where its tip reached the apical foramen, and then, the silicon cursor was adjusted to the tooth incisal edge. This procedure was carried out with 
the aid of a stereo microscope (Carl Zeiss, Jena, Germany) with a magnification of 50x.

The file was removed and the LRC was determined using a ruler with a precision of $0.5 \mathrm{~mm}$ (ARCH, Tokyo, Japan). All the measurements that were needed in this study were performed three times and the average was used as the final LRC.

\section{Electronic determination of the root canal length}

The teeth were divided into two groups $(n=15)$, according to the cervical preparation to be performed:

Group 1 (G1): preparation with $\mathrm{S} 1$ and $\mathrm{Sx}$ by ProTaper system, using the electric motor X-Smart (Dentsply Maillefer, Ballaige, Switzerland) at $300 \mathrm{rpm}$ and torque of $3 \mathrm{~N}$. The instrument $\mathrm{S} 1$ was introduced in the canal up to $3 \mathrm{~mm}$ short of the LRC; afterwards, the instrument Sx was used up to $5 \mathrm{~mm}$ short of the LRC.

Group 2 (G2): preparation with drill LA-Axxess (SybronEndo, California, USA) No. 1 (20.06) at low speed, up to $5 \mathrm{~mm}$ short of the LRC.

Before the cervical preparation, the teeth were immersed into a plastic recipient containing freshly mixed alginate (Jeltrate II, Dentsply, Petropolis, RJ, Brazil) to enable the electronic measurement of the LRC by the EALs Mini Root ZX (j. Morita Corp., Tokyo, Japan) and Joypex 5 (Denjoy, Changsha, China). The labial electrode was inserted into the alginate and laterally to the tooth. The root canals were irrigated with the $1 \%$ $\mathrm{NaOCl}$ solution and its excess was removed from the pulp chamber. A K-type file was connected to the other electrode and slowly inserted in the root canal until the display showed "0.0" or "APEX. The measurements obtained were considered to be correct if the readings remained stable for at least $5 \mathrm{~s}$. Afterwards, the silicone cursor was carefully adjusted according to the reference point and the distance between the cursor and the end of the file was measured. After measurement of each canal was performed 3 times by the EALs evaluated, cervical enlargement was performed in each group, as previously described, and new measurements of LRC were obtained with the EALs.

The accuracy of the EALs was classified as: accurate, if the difference in measurement up to the apical foramen was $\leq 0.5 \mathrm{~mm}$; and inaccurate, if the difference in measurement was $>0.5 \mathrm{~mm}$ or beyond the LRC.

McNemar's Chi-square test was used to detect differences in the accuracy between the samples before and after the cervical preparation with the different instruments, and to detect differences in accuracy between the EALs tested under the same conditions, before and after cervical preparation. The level of significance was established at $\mathrm{P}<0.05$.

\section{RESULTS}

The number of canals with accurate and inaccurate measurements, and the percentage of accurate values for each $E A L$, before and after cervical preparation are shown in Table 1.

A significant increase in accuracy performed by Joypex 5 was observed after cervical preparation with drill LA-Axxes $(P=0.01)$.

Both EALs presented accuracy concerning all canals that were measured after cervical preparation with the S1 and Sx by ProTaper system, without statistical difference between them.

When comparing the EALs evaluated under the same conditions, before and after the cervical preparation with the different instruments, there was no significant difference between them $(P>0.05)$.

Table 1. Number of canals $(n=15)$ with accurate $(\leq 0.5 \mathrm{~mm})$ and inaccurate measurements $(>0.05 \mathrm{~mm})$ and percentage (\%) of accurate results for each EAL, before and after the cervical preparation with the drill LA-Axxess $\mathrm{n}^{\circ} 1$ and $\mathrm{S} 1$ and $\mathrm{SX}$ by Pro-Taper instruments.

\begin{tabular}{|c|c|c|c|c|c|c|c|c|}
\hline \multirow{3}{*}{ Measurements } & \multicolumn{4}{|c|}{ LA-Axxess $n^{\circ} 1$} & \multicolumn{4}{|c|}{ ProTaper S1 e SX } \\
\hline & \multicolumn{2}{|c|}{ Before Preparation } & \multicolumn{2}{|c|}{ After Preparation } & \multicolumn{2}{|c|}{ Before Preparation } & \multicolumn{2}{|c|}{ After Preparation } \\
\hline & JYPB & RZM & JYPA & RZM & JYP & RZM & JYP & RZM \\
\hline$>0.5 \mathrm{~mm}$ & 8 & 6 & 1 & 2 & 3 & 3 & 0 & 0 \\
\hline $\begin{array}{c}\% \text { of accurate } \\
\text { results }\end{array}$ & $46.6 \%$ & $60 \%$ & $93.3 \%$ & $86.6 \%$ & $80 \%$ & $80 \%$ & $100 \%$ & $100 \%$ \\
\hline
\end{tabular}

Note: JYP = Joypex5; RZM = mini Root ZX; Intragroup comparisons: McNemar's test, $\mathrm{P}<$. 01. Different capital letters indicate significant differences regarding the same locator, before and after each type of cervical preparation; intergroup Comparisons: McNemar's test, $P>0.05$. 


\section{DISCUSSION}

Cervical preparation is an essential step during endodontic treatment because it facilitates the reach and the action of instruments in the apical third ${ }^{14-16}$. However, whether enlargement of the cervical third and the type of instrument that is used to accomplish this task are able to significantly affect the precision of the EALs is not yet clear in the literature.

According to the results obtained in this study, it was possible to observe that the use of the drill LA-Axxess in cervical preparation significantly increased the number of accurate measurements for Joypex 5 (Table 1). This increase is similar to those found in previous studies that used other EALs ${ }^{15,20-21}$. This result can be due to a better adjustment of the file to the apical third ${ }^{26}$, promoting less exposure of metallic surface to the surrounding electrolyte and allowing the impedance reading in that region to be more effective ${ }^{10}$

The cervical preparation performed by the mechanical instruments S1 and Sx by ProTaper system promoted $100 \%$ accuracy in the measurements performed with the evaluated EALs; however, there was no statistically significant difference between them and the control group.

In order to be classified as accurate, the required difference between the real and the electronic measurement must be $\leq 0.5 \mathrm{~mm}$; this method was considered to be highly accurate in previous studies ${ }^{22,27}$. According to the results obtained in this study, and also according to other similar studies, the tolerance range was adopted and allowed to observe that after cervical preparation the devices used were highly effective ${ }^{21,27}$. In addition, no cases of over extension were observed, which was similar to the results found by Brito Junior et al. ${ }^{21}$.

The option to assess the accuracy of the EALs at major foramen level $(0.0 \mathrm{~mm})$ was based on studies that obtained satisfactory results using that limit, since the chances of obtaining diverging LRC measurements are higher as there is an increase in the distance between the tip of the file and this limitit2,22. In order to avoid a distortion in the measurement, it is recommended to use the EAL until its display shows "APEX" or $0.0 \mathrm{~mm}$. Afterwards, $1 \mathrm{~mm}$ should be subtracted from the obtained measurement before beginning endodontic treatment ${ }^{5}$.

The experimental models used in ex vivo research aimed at evaluating the accuracy of EALs must simulate clinical situations to reproduce the impedance values in human tissue ${ }^{21}$. For this reason, the material that is commonly used is $1 \%$ agar, saline solution, alginate, gelatin or sponge soaked in saline solution ${ }^{10,24}$. In this study, the teeth were embedded in alginate to perform the measurements, as this Protocol facilitates samples preparation, provides high degree of stability, and leads to accurate measurements ${ }^{20,22}$. Furthermore, it is reported to be the most reliable and reproducible method ${ }^{24}$. Alginate is able to simulate the periodontal ligament due its relative rigidity, favorable electrical conduction properties and jelly-like consistency, which together allow the circulation of the ions ${ }^{24}$.

The results were obtained by a single operator. This was the chosen protocol based on previous studies, which reported significant differences regarding LRC measurements when they were carried out by more than one operator, possibly leading to false results ${ }^{7}$. The difference between operators may be related to their ability and experience in using EALs or to limitations of the electronic device itself 7 .

\section{CONCLUSION}

Cervical preparation performed with the drill LAAxxes increased the accuracy of the Electronic Apex Locator Joypex 5 . Both EALs presented similar precision after cervical preparation, regardless of the instrument used.

\section{Collaborators}

BM GUIMARÃES and MAH DUARTE have substantial contributions to the design of the study and its approval by the Committee for Ethics in Research, data acquisition and interpretation of data, and wrote the paper. T TARTARI performed statistical analysis. SL FERNANDES was also responsible for interpretation of data and wrote the paper. DF ODA contributed to the design of the study and its approval by the Committee for Ethics in Research and interpretation of data. CM BRAMANTE performed the study design and and revised the final version to be published. 


\section{REFERENCES}

1. Nakatsuka AA, Nabeshima CK, Britto MLB. Odontometric reliability of Root ZX II. RGO, Rev Gaúch Odontol. 2012;60(2):215-9.

2. Victorino FR, Lustosa-Pereira A, Bernardineli N, Garcia RB, Moraes IG, Bramante CM. Analysis of accuracy of endodontic millimeter rulers of different commercial brands. RGO, Rev Gaúch Odontol. 2012;60(3):305-8.

3. Guimarães BM, Marciano MA, Amoroso-Silva PA, Alcalde MP, Bramante CM, Duarte MAH. O uso dos localizadores foraminais na endodontia: revisão de literatura. Rev Odontol Bras Central. 2014;23(64):2-7

4. Orosco FA, Bernardineli N, Garcia RB, Bramante CM, Duarte MA, Moraes IG. In vivo accuracy of conventional and digital radiographic methods in confirming root canal working length determination by Root ZX. J Appl Oral Sci. 2012;20(5):522-5. doi: 10.1590/S1678-77572012000500005

5. Cianconi L, Angotti V, Felici R, Conte G, Mancini M. Accuracy of three electronic apex locators compared with digital radiography: an ex vivo study. J Endod. 2010;36(12):2003-7. doi: 10.1016/j. joen.2010.08.036.

6. Chita JJ, Silva PG, Pereira KFS, Onoda HK, Borba Junior JC, Ramos CAS. Precisão e confiabilidade de um novo localizador foraminal eletrônico. Pesq Bras Odontoped Clin Integr. 2012;12(4):457-63. doi: 10.4034/PBOCI.2012.124.02

7. Kielbassa AM, Muller U, Munz I, Monting JS. Clinical evaluation of the measuring accuracy of ROOT ZX in primary teeth. Oral Surg Oral Med Oral Pathol Oral Radiol Endod. 2003;95(1):94-100. doi: 10.1067/moe.2003.99

8. Nekoofar MH, Ghandi MM, Hayes SJ, Dummer PM. The fundamental operating principles of electronic root canal length measurement devices. Int Endod J. 2006;39(8):595-609. doi: 10.1111/j.1365-2591.2006.01131.x

9. Miletic V, Beljic-Ivanovic K, Ivanovic V. Clinical reproducibility of three electronic apex locators. Int Endod J. 2011;44(8):769-76. doi: 10.1111/j.1365-2591.2011.01897.x

10. Stoll R, Urban-Klein B, Roggendorf MJ, Jablonski-Momeni $A$, Strauch K, Frankenberger R. Effectiveness of four electronic apex locators to determine distance from the apical foramen. Int Endod J. 2010;43(9):808-17. doi: 10.1111/j.1365-2591.2010.01765.x

11. Koçak S, Koçak MM, Saglam BC. Efficiency of 2 electronic apex locators on working length determination: a clinical study. J Conserv Dent. 2013;16(3):229-32. doi: 10.4103/09720707.111320

12. Kobayashi C, Suda H. New electronic canal measuring device based on the ratio method. J Endod. 1994;20(3):111-4. doi: 10.1016/S0099-2399(06)80053-1

13. Soares RM, Silva EJ, Herrera DR, Krebs RL, Coutinho-Filho TS. Evaluation of the Joypex 5 and Root ZX II: an in vivo and ex vivo study. Int Endod J. 2013;46(10):904-9. doi: 10.1111/iej.12078

14. Stabholz A, Rotstein I, Torabinejad M. Effect of preflaring on tactile detection of the apical constriction. J Endod. 1995;21(2):92-4. doi: 10.1016/S0099-2399(06)81103-9
15. Ibarrola JL, Chapman BL, Howard JH, Knowles KI, Ludlow MO. Effect of preflaring on Root ZX apex locators. J Endod. 1999;25(9):625-6. doi: 10.1016/S0099-2399(99)80323-9

16. Iqbal A, Akbar I, MK AL-Omiri. An in vivo study to determine the effects of early preflaring on the working length in curved mesial canals of mandibular molars. J Contemp Dent Pract. 2013;14(2):163-7. doi: 1526-3711-1034

17. Qualtrough AJ, Whitworth JM, Dummer PM. Preclinical endodontology: an international comparison. Int Endod J. 1999;32(5):406-14. doi: 10.1046/j.1365-2591.1999.00253.x

18. Davis RD, Marshall JG, Baumgartner JC. Effect of early coronal flaring on working length change in curved canals using rotary nickel-titanium versus stainless steel instruments. J Endod. 2002;28(6):438-42. doi:10.1097/00004770-200206000-00005

19. Ibelli GS, Barroso JM, Capelli A, Spano JC, Pecora JD. Influence of cervical preflaring on apical file size determination in maxillary lateral incisors. Braz Dent J. 2007;18(2):102-6. doi: 10.1590/ S0103-64402007000200003

20. Lipski M, Tr囚bska-囚wistelnicka M, Wo囚niak K, Dembowska E, Dro囚dzik A. Evaluation of alginate as a substitute for rootsurrounding tissues in electronic root canal measurements. Aust Endod J. 2013;39(3):155-8. doi: 10.1111/j.17474477.2012.00367.x

21. Brito-Júnior M, Camilo CC, Moreira-Júnior G, Pecora JD, SousaNeto MD. Effect of pre-flaring and file size on the accuracy of two electronic apex locators. J Appl Oral Sci. 2012;20(5):538-43. doi: 10.1590/S1678-77572012000500008

22. Vasconcelos $B C$, Bueno MM, Luna-Cruz SM, Duarte $M A$ Fernandes CA. Accuracy of five electronic foramen locators with different operating systems: an ex vivo study. J Appl Oral Sci. 2013;21(2):132-7. doi: 10.1590/1678-7757201302188

23. D'Assuncao FL, de Albuquerque DS, Salazar-Silva JR, de Queiroz Ferreira LC, Bezerra PM. The accuracy of root canal measurements using the Mini Apex Locator and Root ZX-II: an evaluation in vitro. Oral Surg Oral Med Oral Pathol Oral Radiol Endod. 2007;104(3):e50-3. doi: 10.1016/j.tripleo.2007.03.025

24. Plotino G, Grande NM, Brigante L, Lesti B, Somma F. Ex vivo accuracy of three electronic apex locators: Root ZX, Elements Diagnostic Unit and Apex Locator and ProPex. Int Endod J. 2006;39(5):408-14. doi: 10.1111/j.1365-2591.2006.01095.x

25. Vertucci F, Seelig A, Gillis R. Root canal morphology of the human maxillary second premolar. Oral Surg Oral Med Oral Pathol. 1974;38(3):456-64. doi: 10.1016/0030-4220(74)90374-0

26. Ebrahim AK, Wadachi $R$, Suda $H$. Ex vivo evaluation of the ability of four different electronic apex locators to determine the working length in teeth with various foramen diameters. Aust Dent $J$. 2006;51(3):258-62. doi: 10.1111/j.1834-7819.2006.tb00439.x

27. Ounsi HF, Naaman A. In vitro evaluation of the reliability of the Root ZX electronic apex locator. Int Endod J. 1999;32(2):120-3. doi: 10.1046/j.1365-2591.1999.00202.x

Received on: 19/7/2015 Final version resubmitted on: 16/12/2015 Approved on: 9/6/2016 